\title{
Downsized Dinosaurs: The Evolutionary Transition to Modern Birds
}

\author{
Luis M. Chiappe
}

Published online: 16 April 2009

(C) Springer Science + Business Media, LLC 2009

\begin{abstract}
Living birds are the most diverse land vertebrates and the heirs of a rich chapter in the evolution of life. The origin of modern birds from animals similar to Tyrannosaurus rex is among the most remarkable examples of an evolutionary transition. A wealth of recently discovered fossils has finally settled the century-old controversy about the origin of birds and it has made the evolutionary saga toward modern birds one of the best documented transitions in the history of life. This paper reviews the evidence in support of the origin of birds from meat-eating dinosaurs, and it highlights the array of fossils that connect these fearsome animals with those that fly all around us.
\end{abstract}

Keywords Dinosaurs · Birds · Origin · Evolution · Mesozoic

With nearly 10,000 living species, birds are the most diverse land vertebrates and are the product of a long and fascinating chapter in the evolution of life. The origin of modern birds is undoubtedly one of the most dramatic examples of an evolutionary transition-one connecting animals akin to the fearsome Tyrannosaurus rex with the feathered marvels we now see all around us - a transformation documented by a wealth of intermediate fossils that date back to the Mesozoic Era (Chiappe 2007), the geologic period that spanned between 245 and 65 million years ago. The importance of the fossil record in providing evidence of intermediate stages in an evolutionary transition has long been recognized (Sues and Anderson 2007). Fossils provide

\footnotetext{
L. M. Chiappe $(\varangle)$

The Dinosaur Institute,

Natural History Museum of Los Angeles County,

900 Exposition Boulevard,

Los Angeles, CA 90007, USA

e-mail: chiappe@nhm.org
}

chronological information about milestones within a transition, they help us visualize the sequence of physical transformations involved in it, and they document a series of intermediate characteristics that are no longer present (or that are highly modified) in extant organisms. Fossils also document that the origin of any major group is accompanied by a wide range of evolutionary experimentation in which closely related lineages - whether contemporaneous or not-approach to a greater or lesser degree the characteristic trademarks of the new group. A wealth of intermediate fossils has made the evolutionary saga toward modern birds one of the best documented transitions in the history of life (Fig. 1).

Birds have an ancient and enormously rich history. The common ancestor of all living groups of birds can be traced to at least the Late Cretaceous period, more than 75 million years ago, and the earliest records of fossils widely accepted as birds - those of the famed Archaeopteryx from southern Germany - date back twice as far. Deciphering the origin of birds, namely, identifying the closest relatives to the most recent common ancestor of Archaeopteryx and modern birds, has been a matter of scientific debate and scrutiny throughout the history of evolutionary biology (Chiappe 2007; Witmer 1991; Chatterjee 1997; Shipman 1998; Feduccia 1999). As early as the eighteenth century, birds were generally placed immediately ahead of flying fishes in the "chains of being" postulated by the naturalists of that time. With the nineteenth century's advent of evolutionary thinking, especially after Darwin's theory of evolution by natural selection, more explicit hypotheses of relationships were formulated. Post-Darwinian times witnessed a diversity of hypotheses in which birds were considered to be most closely related to a variety of extinct and extant lineages of reptiles. These hypotheses related birds to groups of animals such as turtles, crocodiles, and their relatives, various primitive Triassic fossils (245 to 208 


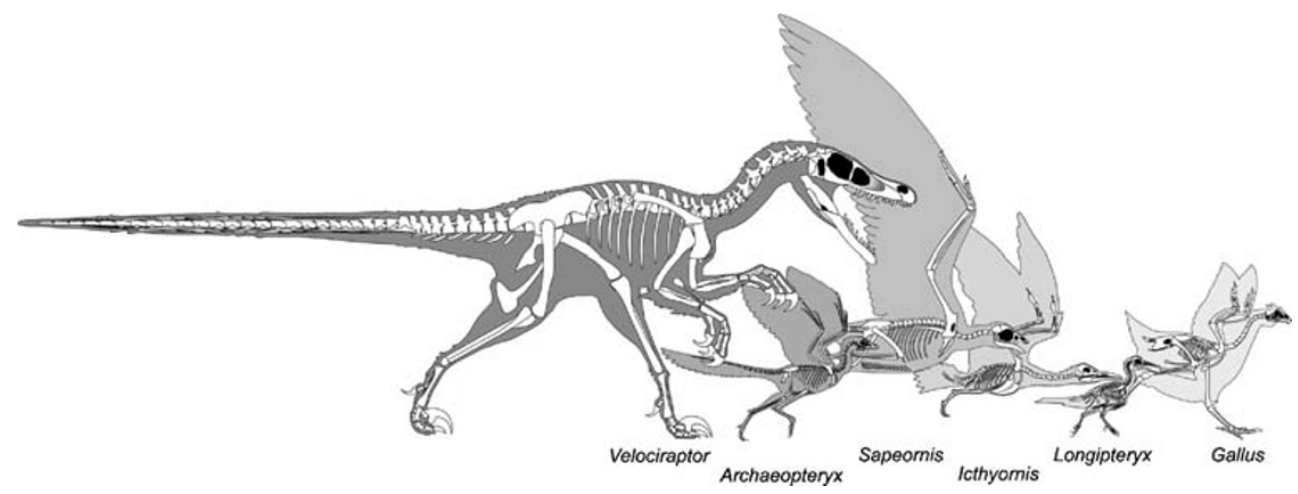

Fig. 1 The skeletons of the nonavian maniraptoran Velociraptor, the Jurassic bird Archaeopteryx, the Early Cretaceous short-tailed bird Sapeornis and enantiornithine Longipteryx, the Late Cretaceous Ichthyornis, and the living Gallus (chicken). In recent years, a wealth

million years ago), pterodactyls, and their kin, and the plant-eating ornithischians and the meat-eating theropod dinosaurs. For decades, the origin of birds remained obscure and controversial - the fossil record was too fragmentary to provide a clear picture. Today, however, most of the other hypothetical relationships have been abandoned and the theropod hypothesis has received nearly universal acceptance (Shipman 1998; Rowe et al. 1998; Sereno 1999; Chiappe and Witmer 2002). In fact, because birds are overwhelmingly interpreted as the descendants of a group of carnivorous dinosaurs, most scientists argue that they be considered living dinosaurs. Therefore, birds are today interpreted as avian dinosaurs-Velociraptor, Tyrannosaurus, Brachiosaurus, and all other traditional "dinosaurs" that coexisted with a variety of primitive Mesozoic birds are referred to as nonavian dinosaurs.

\section{Birds as Living Dinosaurs}

The idea that the ancestry of birds can be traced back to a group of carnivorous dinosaurs called theropods is not new (Chiappe 2007). Nearly 150 years ago, soon after the publication of Darwin's Origin of Species, German embryologist C. Gegenbaur used similarities in the structure of the ankle to place the small, 150-million-year-old theropod Compsognathus in an intermediate position between birds and other reptiles. At about the same time, American paleontologist E.D. Cope compared the ankle of the Jurassic theropod Megalosaurus to that of an ostrich, and on the basis of this and other skeletal similarities, argued for a close relationship of theropods and birds. Despite these initial considerations, it was British anatomist T.H. Huxley (Huxley 1868) who first popularized the idea that birds had originated within theropod dinosaurs. In the ensuing years, a myriad of other skeletal features supporting the dinosaurian origin of birds has been discovered in of bird-like nonavian maniraptorans and primitive ("dinosaur"-like) birds have been unearthed from Mesozoic rocks worldwide-these discoveries have consolidated the notion that birds evolved from maniraptoran theropod dinosaurs. Drawings not to scale

the fossils of large and small theropods. Since the 1960s, a greater understanding of small predatory dinosaurs of the Cretaceous age, such as the dromaeosaurid Deinonychus (Ostrom 1969, 1976), has led to the idea that birds had originated from within a group of bird-like theropods called maniraptorans (Gauthier 1986). Today, the skeletons of such maniraptoran theropods such as the sickle-clawed dromaeosaurids (Deinonychus, Velociraptor, and their kin; Fig. 1), the lightly built troodontids (Troodon, Mei, and their kin), the parrot-headed oviraptorids (Oviraptor and relatives), and the short-armed alvarezsaurids (Mononykus and its kin) are recognized as sharing a great deal of similarity with birds (Chiappe and Witmer 2002; Weishampel et al. 2004). Not only have birds retained the bipedalism, hollowed bones, and the three fully developed toes of their theropod predecessors, but these animals also share a series of air spaces connected to the ear region, unique structures of their vertebral column and rib cage, elongate forelimbs with wrist bones allowing swivel-like movements of the hand and similar structures in the pelvis and hindlimbs, as well as many other characteristics distributed over the entire skeleton (Rowe et al. 1998; Sereno 1999; Chiappe and Witmer 2002; Weishampel et al. 2004; Novas and Puerta 1997; Holtz 1998). Indeed, many skeletal features previously thought to be exclusively avian - such as wishbones, laterally facing wingpits, and large breastbones - have now been discovered among nonavian maniraptorans (Padian and Chiappe 1998).

In recent years, a wealth of evidence taken from comparisons between the skeletons of these dinosaurs and those of birds has been supplemented by diverse lines of evidence in support of the same evolutionary relationship. Paleontologists have determined that the shape and structure of nonavian maniraptoran eggs were similar to those of living birds (Mikhailov 1992; Zelenitsky 2006; Varricchio and Jackson 2004; Grellet-Tinner et al. 2006). Some of these features involve the presence of more than one 
distinct crystalline layer in the eggshell (distinguished by a differential disposition of eggshell crystals), reduction in the number of airholes perforating the eggshell, a relative increase in the volume of the egg (with respect to the adult's size), and the development of asymmetrical eggs in which one pole is narrower than the other (Fig. 2). Snapshots of ancient behavior revealed by a handful of exceptional fossils have also provided support to the hypothesis that birds evolved from maniraptoran dinosaurs. The discovery of a "gravid" oviraptorid female containing a pair of shelled eggs inside her pelvic canal (Sato et al. 2005) has confirmed previous interpretations based on the spatial arrangement of eggs within clutches of nonavian maniraptorans. These clutches - particularly well known among oviraptorids - show that the eggs were arranged in pairs, as opposed to typical reptilian clutches (turtles, crocodiles, and other dinosaurs), in which the eggs lack any spatial arrangement (Grellet-Tinner et al. 2006) (Fig. 2). This evidence indicates that, as with birds, nonavian maniraptorans laid their eggs sequentially, at discrete time intervals. It probably took several days for a nonavian maniraptoran female to lay its egg clutch (Varricchio and Jackson 2004; Grellet-Tinner et al. 2006), a condition shared with birds.

Other extraordinary discoveries have shed light on the nesting behavior of these dinosaurs. Skeletons of oviraptorids (Norell et al. 1995; Clark et al. 1999) and troodontids (Varricchio and Jackson 2004) have been discovered on top of their clutches of eggs. The fossils show evidence that these animals adopted a posture similar to that of brooding birds. In oviraptorids, the adult tucked its legs inside an open space at the center of the egg-clutch and hugged the periphery of the clutch with its long forelimbs; in the more lightly built troodontids, the adult sat on top of the vertically buried eggs. These discoveries suggest that, regardless of its specific role (protection, incubation), typical avian nesting behaviors (adults sitting on top of their nests) were widespread among nonavian maniraptorans. Additional evidence further documents behavioral similarities with birds. Fossils of troodontids with their skeleton arranged such that the hindlimbs are flexed
Fig. 2 Characteristics of the eggs and clutches of several nonavian maniraptorans support the inclusion of birds within these theropod dinosaurs. For example, the presence of at least two distinct crystalline layers in the eggshell and the existence of an asymmetric egg (less asymmetric among oviraptorids) can be traced back to as far as the maniraptoran divergence. The distribution of the eggs within a clutch in oviraptorids indicates that these dinosaurs laid their eggs sequentially (other evidence also indicates that, as in the case of birds, they also brooded their clutch)

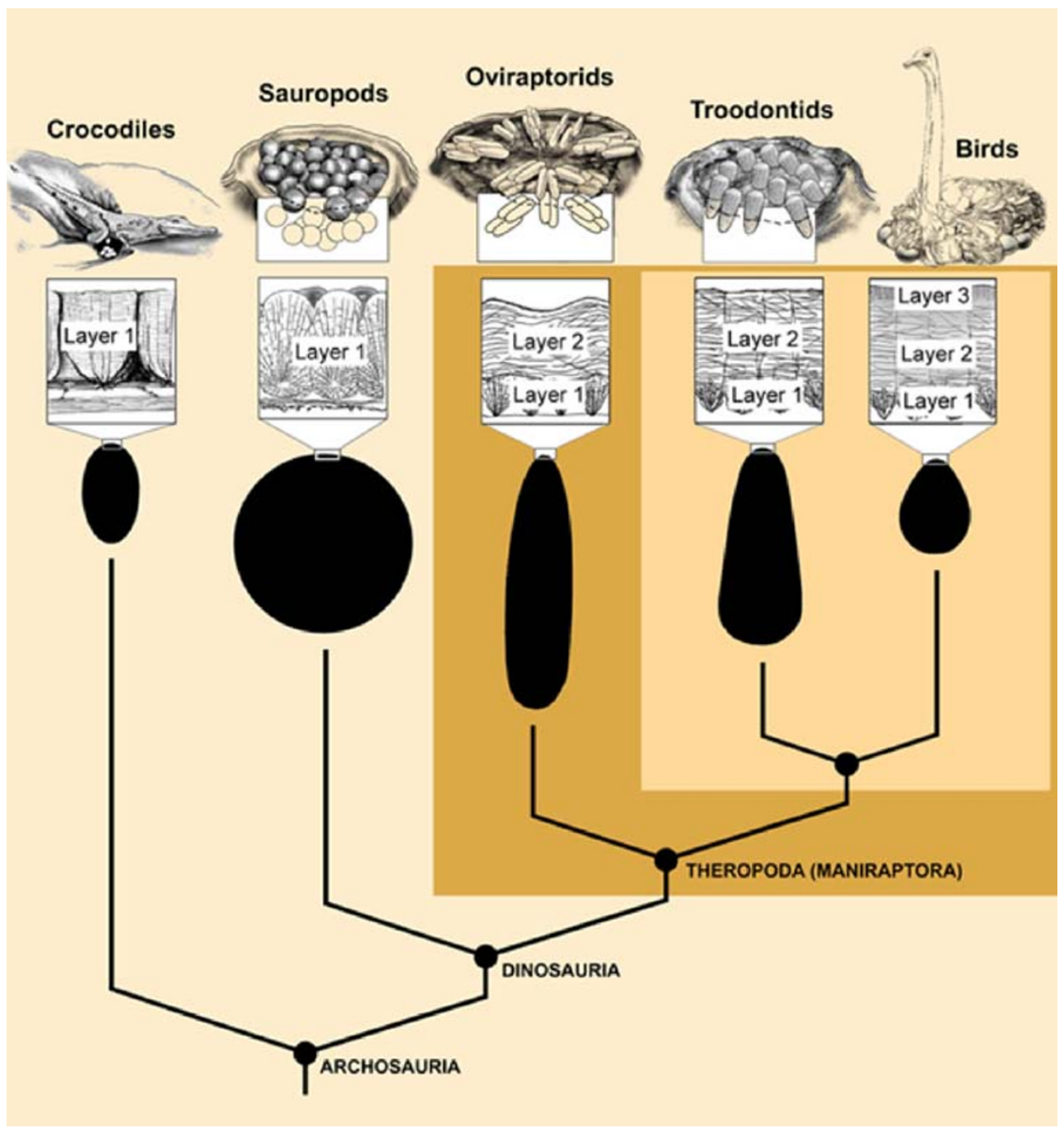


beneath the belly, the neck is turned backwards, and the head is tucked between the wing and the body have documented that at least some of the maniraptoran precursors of birds had already evolved stereotypical resting poses familiar to many birds (Xu and Norell 2004).

More specific fields of research have made their own empirical contributions in support of the dinosaurian legacy of birds. Studies of dinosaurian growth rates, based on details preserved in the fossilized tissue of their bones, have documented that these animals, once believed to be slowgrowing, actually grew at speeds comparable to many living birds (Erickson et al. 2001), and special bone tissues, such as the medullary bone characteristic of ovulating birds, have been documented in a female $T$. rex (Schweitzer et al. 2005). Evidence in support of the evolutionary transition between nonavian dinosaurs and birds has also been uncovered from disciplines as far-off from classic paleontology as genetics. Studies correlating the sizes of bone cells and genomes (the entire genetic material of an organism) have revealed that the mighty $T$. rex and its fearsome kin had the small genomes typical of modern birds (Organ et al. 2007), and putative protein sequences from soft tissues of this dinosaur have also highlighted its evolutionary closeness to birds (Organ et al. 2008, although for a different interpretation of this evidence, see Dalton 2008).

Yet, despite the multiplicity of this extensive body of evidence, nothing has cemented the dinosaurian pedigree of birds more than the realization that true feathers-the quintessential avian feature-may have covered the bodies of a variety of nonavian dinosaurs (Norell and $\mathrm{Xu}$ 2005). The enormous significance of these fossils notwithstanding, the documented existence of feathers in nonavian dinosaurs has, thus far, been limited to a dozen or so species, all of them circumscribed to the Cretaceous deposits of East Asia. Some of these dinosaurs exhibit feathers that are filamentlike, with a minimal degree of branching, but a number of others display pennaceous feathers with distinct shafts and vanes. In certain nonavian maniraptorans, long pennaceous feathers attach to the distal part of the tail, either in a fanlike fashion or giving the tail the frond-like appearance common to primitive birds such as Archaeopteryx (Fig. 1a). Long pennaceous feathers also attach to the tip of the forelimbs of some of these maniraptorans, and in the case of the peculiar dromaeosaurid Microraptor (Norell and $\mathrm{Xu}$ 2005), they form a wing of essentially modern design. Despite the evidence of plumage being restricted to a handful of nonavian dinosaurs, the fact that these fossils span a large portion of the family tree of theropods and display a great diversity of sizes, appearances, and lifestyles, hints at a much larger and yet undocumented diversity (Fig. 3) - even the colossal T. rex may have been covered with a cloak of feathers at some early stage of its life. It is an amazing experience to gaze at the entirely modern feathers of animals, whereas their skeletal characteristics are so unquestionable dinosaurian.
Fig. 3 Genealogical relationships of feathered nonavian theropods. Current evidence supports the hypothesis that filamentous and vaned feathers evolved with the divergence of coelurosaurs and maniraptorans, respectively

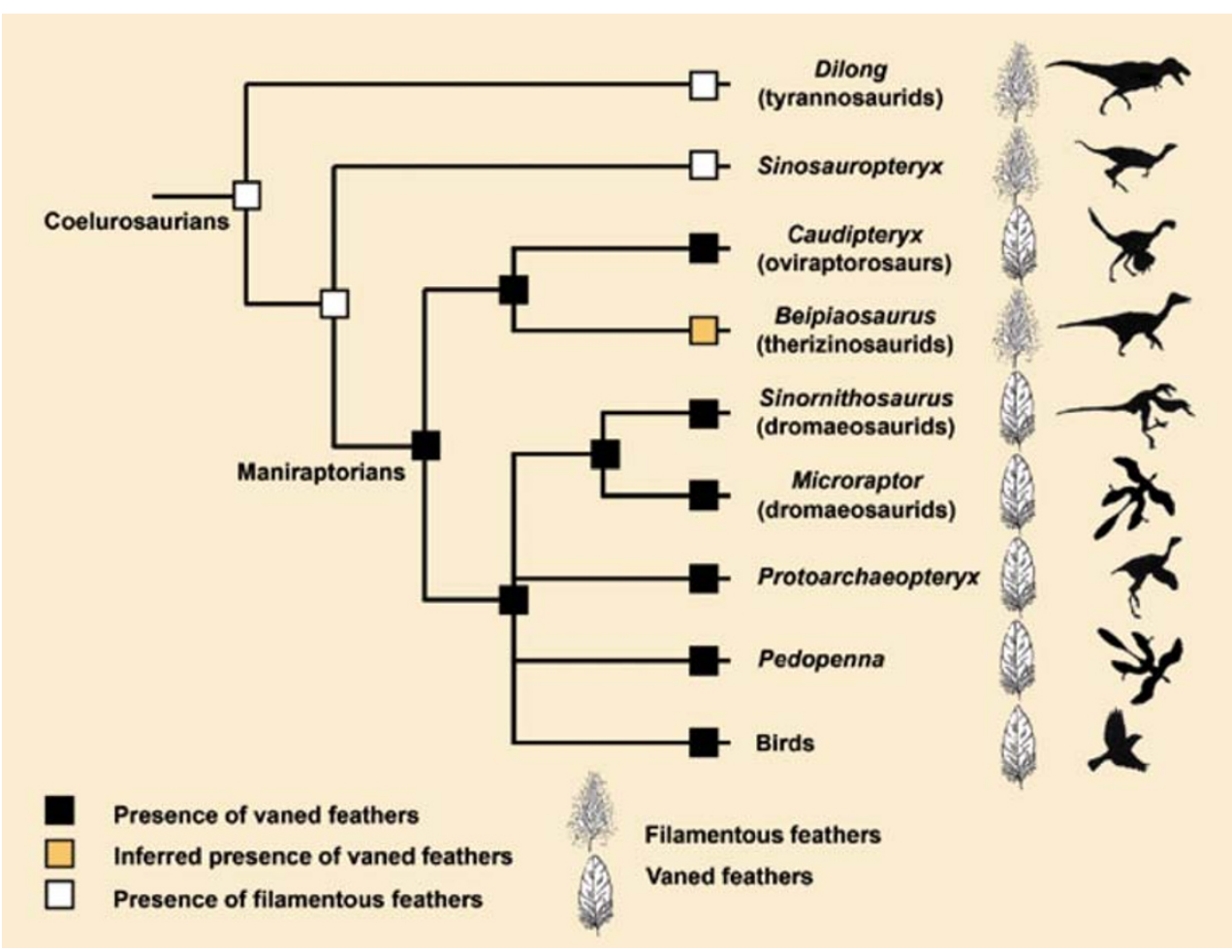


An important corollary of these discoveries is that feathers did not evolve in the context of flight. With the sole exception of Microraptor, it is certain that none of these feathered dinosaurs were able to take to the air. The forelimbs and their feathers are both much shorter than in flying birds and their bodies are larger. The evolutionary transition toward birds and the origin of their flight involved a dramatic reduction in body size. These feathered dinosaurs indicate that, at their onset, feathers must have had a different function, perhaps insulating the bodies of animals that had metabolically diverged from their coldblooded, reptilian ancestors. My research has suggested that vaned feathers may have originated in the context of thrust, evolving in running nonavian theropods that by flapping their feathered arms were able to increase their running speed (Burgers and Chiappe 1999). In the end, however, we simply do not have an answer for what was the original function of feathers; nonetheless, we have been able to eliminate flight as an option.

Today, the century-old debate on bird ancestry has largely been resolved. The uncertainties that led to this long controversy - both empirical and methodologicalhave been clarified and there is an overwhelming consensus in support of the idea that birds evolved from maniraptoran theropods. Current evidence highlights the fact that many features previously thought to be exclusively avian - from feathers to a wishbone - have now been discovered in the immediate dinosaur predecessor of birds. The origin of birds was also preceded by a substantial reduction in body sizethe most primitive members of groups such as troodontids and dromaeosaurids are smaller than one meter long (Turner et al. 2007). This notable reduction in the size of the forebears of birds was an important prerequisite of flight; even this most characteristic avian attribute is likely to have been inherited by birds from their dinosaurian predecessors.

The comparative studies that have been the building blocks of these important evolutionary conclusions have been greatly assisted by many newly discovered Mesozoicaged birds (Chiappe 2007), which by possessing many skeletal features that are only slightly modified from the ancestral maniraptoran condition, fill a critical gap in the evolutionary transition toward modern birds (Figs. 1, 4, and 5). This newly-discovered fossil menagerie has unveiled an unexpected diversity of archaic birds that would take birding to another dimension. These new discoveries are reviewed next.
Fig. 4 Cladogram or diagram depicting the genealogical relationships among the main lineages of premodern birds and some lineages of nonavian maniraptoran dinosaurs. The known fossil record of these groups is also highlighted. The concept of a dove as a living dinosaur-because they share a common descent - may seem bizarre, but, in reality, it is just as logical as the argument that humans are primates because we evolved from primates

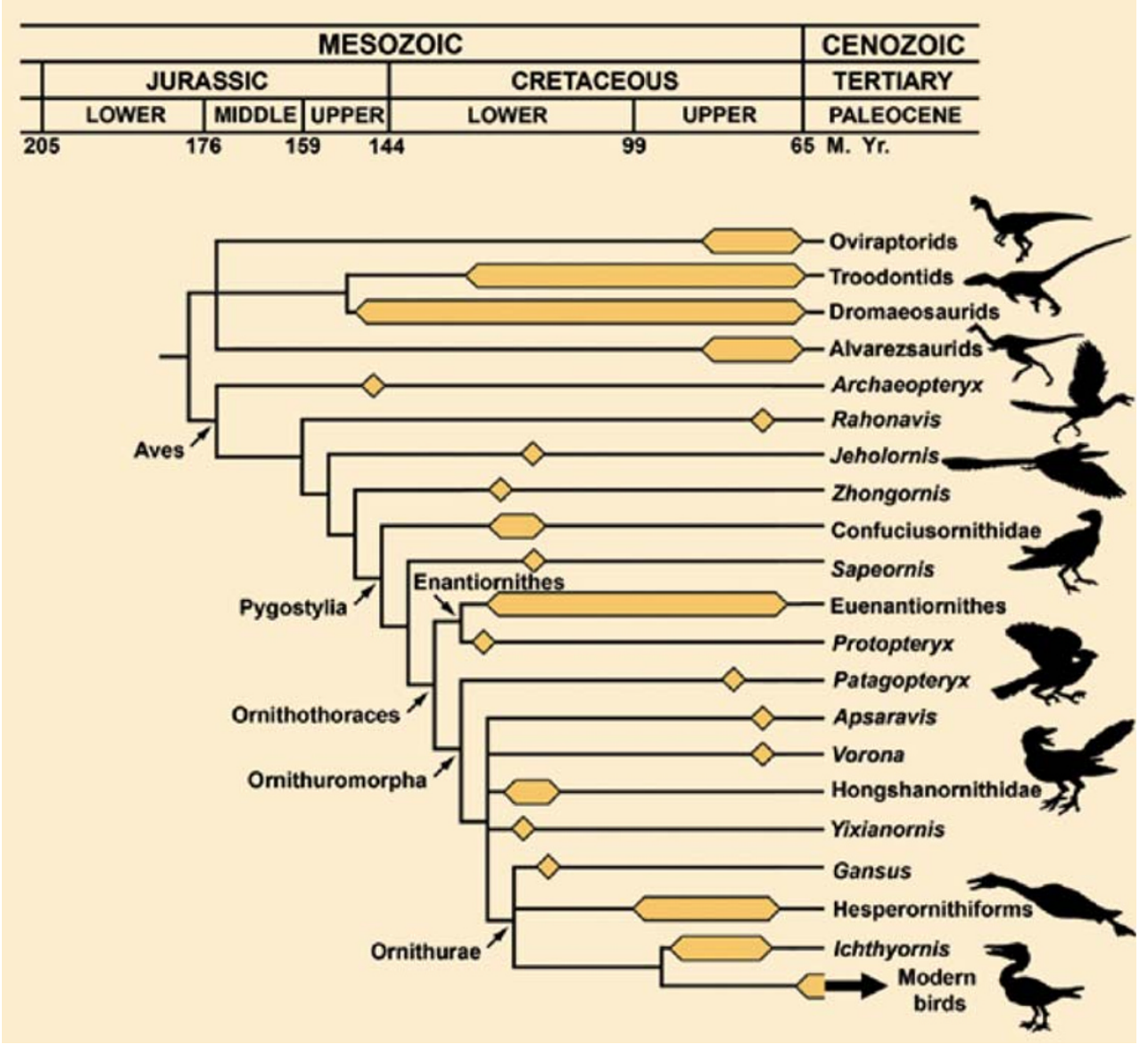



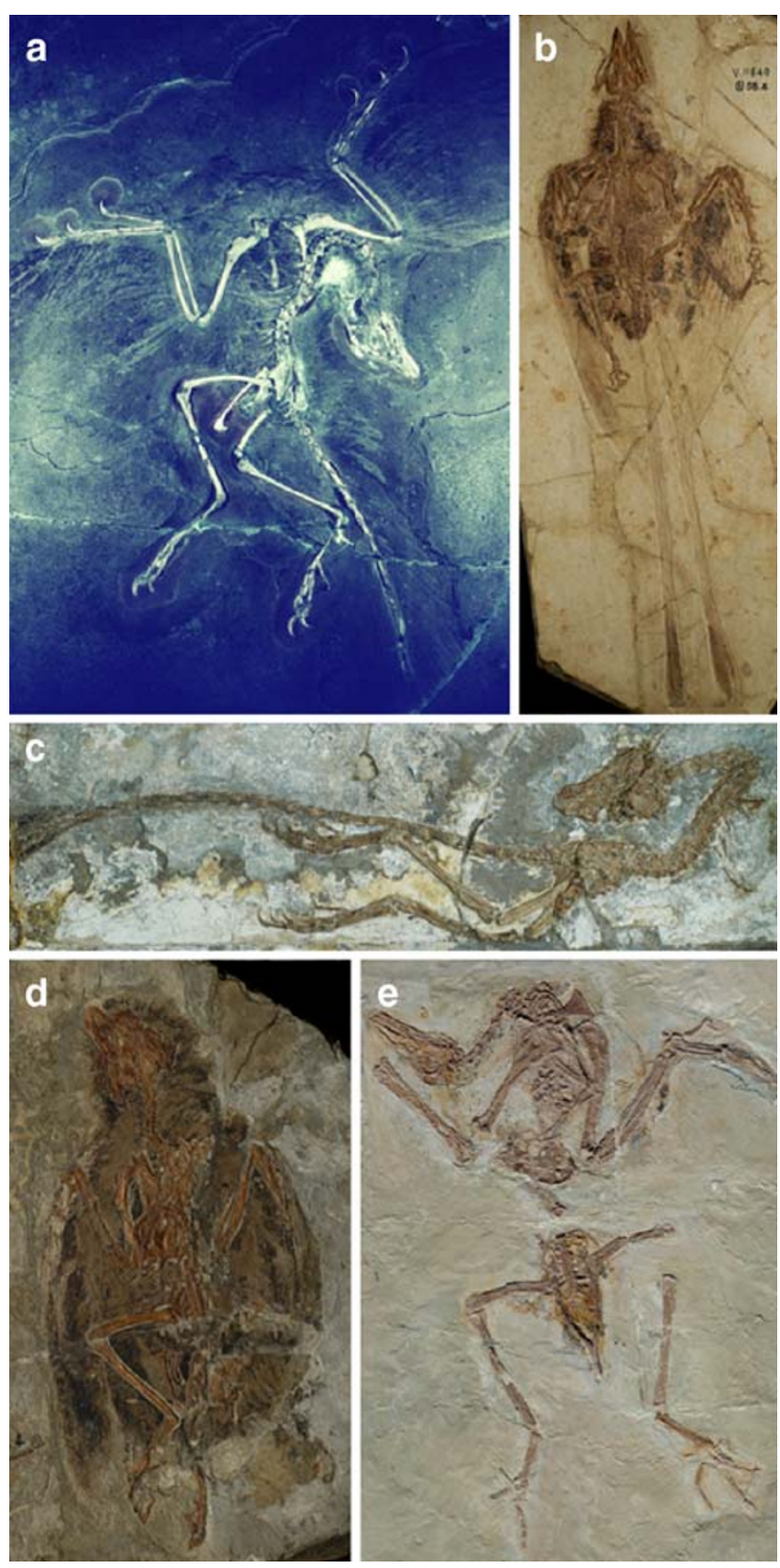

Fig. 5 Photographs of the Berlin specimen of the Late Jurassic Archaeopteryx (a), the Early Cretaceous short-tailed bird Confuciusornis (b), long-tailed bird Jeholornis (c), enantiornithine Eoenantiornis (d), and primitive ornithuromorph Yanornis (e). Photographs not to scale

\section{The Long March Toward Modern Birds}

Research on the early history of birds and the development of flight has been at the forefront of paleontology since the advent of evolutionary thought. For most of this time, however, the available evidence was limited to a small number of fossils largely restricted to near-shore and marine environments and was greatly separated both anatomically and in time. In the last few decades, however, our understanding of the origin and ancient divergences of birds has advanced at an unparalleled rate. This rapid increase in discoveries has not only filled much of the anatomical and temporal gaps that existed previously, but has also made the study of early birds one of the most dynamic fields of vertebrate paleontology.

New information highlights the fact that the enormous diversity of living birds is just a remnant of an archaic evolutionary radiation that can be traced back to Archaeopteryx (Mayr et al. 2005) (Figs. 1 and 4). Few physical features set this most ancient bird apart from its theropod dinosaur predecessors. However, Archaeopteryx gives us paramount clues to the beginning of one of the most dramatic evolutionary events in the history of vertebratesthe development of powered flight in birds. This 150million-year-old jay-sized bird with toothed jaws, clawed wings, and a long bony tail stands alone in the fossil record of birds of the end of the Jurassic period. Yet, in the last decade, a large number and variety of birds have been found in early Cretaceous rocks ranging from 130 to 115 million years ago (Chiappe 2007; Zhou 2004). These fossils reveal that a great diversity of birds with long bony tails preceded the evolution of birds with an abbreviated bony tail (Forster et al. 1998; Zhou and Zhang 2003), one composed of fewer vertebrae ending in a bony stump called a pygostyle (the structure that supports the "parson's nose"). Characteristics of the plumage, the large wing size, and specific features of their brain all suggest that Archaeopteryx and the remaining long-tailed birds were fliers, even if these birds probably required a take-off run to become airborne (Burgers and Chiappe 1999).

A rich diversity of more advanced birds is also recorded in these early Cretaceous rocks. In fact, the differing design of skulls, teeth, wings, and feet indicate that, even at this early phase of their evolutionary history, birds had specialized into a variety of ecological niches, including seed-feeders, insect-feeders, fish-eaters, and meat-eaters (Chiappe 2007). At the same time, a host of novel features of the wings, shoulders, and tails suggests that, soon after Archaeopteryx, birds evolved flying abilities not very different from the ones that amaze us today, a feat that was most likely the recipe for their dramatic diversification during the Cretaceous. Paramount among these transformations is the abbreviation of the tail and the consequent development of a pygostyle. Yet, the details of this evolutionary transition are far from clear. One recent fossil that has shed some light onto this transition is the tiny, 125million-year-old Zhongornis (Gao et al. 2008) from northeastern China. Zhongornis is the first bird discovered that has a short tail and a corresponding reduced number of tail vertebrae, yet lacks the pygostyle that is present in all other short-tailed birds. Therefore, Zhongornis represents 
an intermediate stage between the primitive long-tailed birds and those with a bony stump at the end of the tail. Evidence from the skeleton of Zhongornis suggests that a short tail with a reduced number of vertebrae evolved earlier in birds than did the pygostyle.

Very early in their evolutionary history, short bony-tailed birds blossomed in a range of shapes and sizes. Hundreds of specimens of the stout-beaked Confuciusornis, many surrounded by a halo of dark feathers, have been unearthed from the 125-million-year-old deposits of northeastern China (Chiappe et al. 1999) (Fig. 5). This crow-sized bird sported long hands with enormous claws and long and tapering wings. Growth series of Confuciusornis spanning a large spectrum of sizes suggest that, unlike modern birds, this and other archaic birds required multiple years to reach adult size (Chiappe 2007). The contemporaneous and much larger Sapeornis had longer and narrower wings, superficially resembling those of albatrosses (Zhou and Zhang 2002) (Fig. 1). Albeit bearing stout teeth and a very primitive shoulder, the anatomy of this bird suggests a closer relationship to modern birds than Confuciusornis. Combined, however, these fossils best illustrate the anatomy and appearance of the most primitive short-tailed birds, which, by virtue of their proportionally larger wings, were likely better fliers than their long-tailed predecessors.

Fossils of more advanced birds are also first recorded at around 130 million years ago. Among these are the enantiornithines (Chiappe 2007; Chiappe and Witmer 2002), a group that constitutes the most important evolutionary radiation of premodern birds. Like most early birds, the majority of enantiornithines had toothed jaws and partially clawed wings (Figs. 1 and 5). Yet their skeletons show a series of key transformations that approach those of today's birds. Some of these include the shortening of the hand and fingers as well as changes in the proportions of the wing bones and the anatomy of the shoulder. Furthermore, these birds evolved important innovations in their plumage, namely, a safety device called the alula (a small tuft of feathers also known as the "bastard wing"), which assists modern birds during their take-off and landing (Sanz et al. 1996). The significant transformations of the skeleton and plumage of these birds suggest that, even at the onset of their evolutionary history, enantiornithines were able to take-off from a standstill position and maneuver in ways similar to those seen among living birds. It is most likely that the evolution of these enhanced flying capabilities played a key role in the evolutionary success of the enantiornithines, which by about 120 million years ago seem to have risen to dominance.

Rocks from the early Cretaceous also record a number of transitional fossils that herald the evolution of the closest relatives of modern birds (Fig. 1). In some respects, these primitive ornithuromorphs (Chiappe 2007; Chiappe and
Witmer 2002; Zhou 2004; Zhou and Zhang 2005) resemble the enantiornithines, but their skeletons show, for the first time, clear trademarks of their living counterparts. The majority of these primitive ornithuromorphs were lightly built, flying birds, whose sizes tend to be larger than those of their contemporaneous enantiornithines. Like the latter, both their skeletons and plumage show clear evidence of enhanced aerodynamic capabilities. It is within these birds that we witness the origin of the extremely fast rates of body maturation characteristic of modern birds (Chiappe and Witmer 2002), which reach their full body size within a year after hatching.

As the rocks of the Cretaceous period become younger, a series of other lineages of ornithuromorphs make their debut. The hesperornithiforms-large, flightless, footpropelled divers - first appear around 100 million years ago (Chiappe 2007; Chiappe and Witmer 2002). Albeit entirely restricted to the aquatic realm, the hesperornithiforms exhibit a rich and diverse evolutionary history spanning over 35 million years - their last representatives may have disappeared with the latest Cretaceous mass extinction that wiped out the last of the nonavian dinosaurs. Despite the fact that their earliest records represent birds the size of a loon, millions of years later, these supreme fisheaters would be crowned kings of the aquatic birds with a number of large forms such as the tiny-winged, four-foot long Hesperornis and Asiahesperornis. The hesperornithiforms swam the waters of tropical seas that, during the late Cretaceous, divided in half both North America and Eurasia. On the shore of these shallow seas, over herds of duck-billed and other kinds of dinosaurs, soared the ternsized Ichthyornis (Clarke 2004) (Fig. 1). In most respects, this bird represents a step closer to modern birds, yet it had sharply toothed jaws designed to catch fish. Ichthyornis is perhaps the best-known, closest relative of modern birds; other late Cretaceous fossils seemingly close to the latter are known by much more fragmentary remains.

Not all the birds that lived during the Mesozoic may have looked as unfamiliar as Archaeopteryx, Confuciusornis, and Hesperornis. The early representatives of today's lineages of birds can also be traced back to this remote era of our geological past. In several continents, rocks from the last part of the Cretaceous period- -75 to 65 million years ago - reveal the remains of early shorebirds, ducks, and other familiar birds (Kurochkin et al. 2002; Clarke et al. 2005). These discoveries indicate that a number of modern lineages had their origins prior to the end of the Mesozoic. It is unclear how these early representatives of modern birds managed to survive the devastating mass extinction of the end of the Cretaceous, but these survivors diversified soon after into a myriad of forms, which today carry the legacy of the magnificent dinosaurs that ruled the earth tens of millions of years ago. 


\section{The Dinosaur in your Backyard}

In the last few decades, our understanding of the origin and subsequent evolutionary diversification of birds has advanced at an unparalleled pace. These fossil discoveries have documented the stepwise nature of one of the most fascinating evolutionary transitions, and they have filled the large gap that separated living birds from their dinosaurian predecessors. This new evidence has shown that many of the features previously considered to be avian trademarks first evolved within theropod dinosaurs.

The strength of the hypothesis that birds evolved within maniraptoran theropod dinosaurs is manifested by the convergent results of a diversity of studies within a multitude of scientific disciplines. Today, the theropod origin of birds is supported by a wealth of evidence ranging from skeletal anatomy to molecular data. This evolutionary conclusion indicates that the diverse modern birds are a branch of a much larger avian tree that diverged during the Mesozoic era and that, in turn, all these birds are but a shoot of the majestic tree of dinosaurs. This evidence has led to the realization that the jays, finches, and hummingbirds that so peacefully frequent your backyard are indeed living dinosaurs - a surviving lineage of vicious predators that ruled the terrestrial ecosystems of the Mesozoic.

\section{References}

Burgers P, Chiappe LM. The wing of Archaeopteryx as a primary thrust generator. Nature 1999;399:60-2. doi:10.1038/19967.

Chatterjee S. The rise of birds: 225 million years of evolution. Baltimore: John Hopkins University Press; 1997. p. 312.

Chiappe LM. Glorified dinosaurs. New York: Wiley; 2007. p. 263.

Chiappe LM, Witmer LM. Mesozoic birds: above the heads of dinosaurs. Berkeley: University of California Press; 2002. p. 520.

Chiappe LM, Ji S, Ji Q, Norell MA. Anatomy and systematics of the Confuciosornithidae (Aves) from the Late Mesozoic of northeastern China. Bull Am Mus Nat Hist. 1999;242:1-89.

Clark JM, Norell MA, Chiappe LM. An oviraptorid skeleton from the Late Cretaceous of Ukhaa Tolgod, Mongolia, preserved in an avian-like brooding position over an oviraptorid nest. Am Mus Novit. 1999;3265:1-36.

Clarke JA. Morphology, phylogenetic taxonomy, and systematics of Ichthyornis and Apatornis (Avialae: Ornithurae). Bull Am Mus Nat Hist. 2004;286:1-179. doi:10.1206/0003-0090(2004) 286<0001:MPTASO $>2.0 . \mathrm{CO} ; 2$.

Clarke JA, Tambussi CP, Noriega JI, Erickson GM, Ketchum RA. Definitive fossil evidence for the extant avian radiation in the Cretaceous. Nature 2005;433:305-8. doi:10.1038/nature03150.

Dalton R. Fresh doubts over T. rex chicken link. Nature 2008;454: 1035. doi: $10.1038 / 4541035 \mathrm{a}$

Erickson GM, Curry-Rogers K, Yerby SA. Dinosaurian growth patterns and rapid avian growth rates. Nature 2001;412:429-33. doi: $10.1038 / 35086558$.

Feduccia A. The origin and evolution of birds. 2nd ed. New Haven: Yale University Press; 1999. p. 466.
Forster CA, Sampson SD, Chiappe LM, Krause DW. The theropodan ancestry of birds: new evidence from the Late Cretaceous of Madagascar. Science 1998;279:1915-9. doi:10.1126/science. 279.5358.1915.

Gao C, Chiappe LM, Meng Q, O'Connor JK, Wang X, Cheng X, et al. A new basal lineage of Early Cretaceous birds from China and its implications on the evolution of the avian tail. Palaeontology 2008;51(4):775-91. doi:10.1111/j.1475-4983.2008.00793.x.

Gauthier JA. Saurischian monophyly and the origin of birds. In: Padian K, editor. The origin of birds and the evolution of flight. Berkeley: California Academy of Science; 1986. p. 1-55.

Grellet-Tinner G, Chiappe LM, Norell M, Bottjer D. Dinosaur eggs and nesting behaviors: their paleobiological inferences. Palaeogeogr Palaeoclimatol Palaeoecol. 2006;232:294-321. doi:10. 1016/j.palaeo.2005.10.029.

Holtz TR Jr. A new phylogeny of the carnivorous dinosaurs. Gaia 1998;15:5-61.

Huxley TH. On the animals which are most nearly intermediate between the birds and the reptiles. Ann Mag Nat Hist. 1868; 2:66-75.

Kurochkin EN, Dyke GJ, Karhu AA. A new presbyornithid bird (Aves, Anseriformes) from the Late Cretaceous of Southern Mongolia. Am Mus Novit. 2002;3386:1-11. doi:10.1206/00030082(2002)386<0001:ANPBAA>2.0.CO;2.

Mayr G, Pohl B, Peters DS. A well-preserved Archaeopteryx specimen with theropod features. Science 2005;310:1483-6. doi:10.1126/ science. 1120331.

Mikhailov KE. The microstructure of avian and dinosaurian eggshell: phylogenetic implications. Nat Hist Mus Los Angeles Cty. 1992;36:361-73.

Norell MA, Xu X. Feathered dinosaurs. Annu Rev Earth Planet Sci. 2005;33:277-99. doi:10.1146/annurev.earth.33.092203.122511.

Norell MA, Clark JM, Chiappe LM, Dashzeveg D. A nesting dinosaur. Nature 1995;378:774-6. doi:10.1038/378774a0.

Novas FE, Puerta P. New evidence concerning avian origins from the Late Cretaceous of Patagonia. Nature 1997;387:390-2. doi:10. 1038/387390a0.

Organ CL, Shedlock AM, Pagel M, Edwards SV. Origin of avian genome size and structure in non-avian dinosaurs. Nature 2007;446:180-4. doi:10.1038/nature05621.

Organ CL, Schweitzer MH, Zheng W, Freimark LM, Cantley LC, Asara JM. Molecular phylogenetics of mastodon and Tyrannosaurus rex. Science 2008;320:499. doi:10.1126/science.1154284.

Ostrom JH. Osteology of Deinonychus antirrhopus, an unusual theropod from the lower Cretaceous of Montana. Bull Peabody Mus Nat Hist. 1969;30:1-165.

Ostrom JH. Archaeopteryx and the origin of birds. Biol J Linn Soc Lond. 1976;8:91-182. doi:10.1111/j.1095-8312.1976.tb00244.x.

Padian K, Chiappe LM. The origin and early evolution of birds. Biol Rev Camb Philos Soc. 1998;73:1-42. doi:10.1017/S0006323 197005100.

Rowe T, Kishi K, Merck J Jr, Colbert M. The age of dinosaurs. 3rd ed. Educational interactive multimedia on CD-ROM for Macintosh and PC computers. New York: Freeman; 1998.

Sanz JL, Chiappe LM, Perez-Moreno BP, Buscalioni AD, Moratalla J. A new Lower Cretaceous bird from Spain: implications for the evolution of flight. Nature 1996;382:442-5. doi:10.1038/ $382442 \mathrm{a} 0$.

Sato T, Cheng Y, Wu X, Zelenitsky DK, Hsiao Y. A pair of shelled eggs inside a female dinosaur. Science 2005;308:375. doi:10. 1126/science. 1110578 .

Schweitzer MH, Wittmeyer JL, Horner JR. Gender-specific reproductive tissue in ratites and Tyrannosaurus rex. Science 2005;308: 1456-60. doi:10.1126/science.1112158.

Sereno PC. The evolution of dinosaurs. Science 1999;284:2137-47. doi:10.1126/science.284.5423.2137. 
Shipman P. Taking wing. New York: Simon \& Schuster; 1998. p. 320.

Sues HD, Anderson JS. Introduction: studying evolutionary transitions among vertebrates. In: Sues H-D, Anderson JS, editors. Major transitions in vertebrate evolution. Bloomington: Indiana University Press; 2007. p. 1-12.

Turner AH, Pol D, Clarke JA, Erickson GM, Norell MA. A basal dromaeosaurid and size evolution preceding avian flight. Science 2007;317:1378-81. doi:10.1126/science.1144066.

Varricchio DV, Jackson F. Two eggs sunny-side up: reproductive physiology in the dinosaur Troodon formosus. In: Currie PJ, Koppelhus EB, Shugar MA, Wright JL, editors. Feathered dragons: studies on the transition from dinosaurs to birds. Bloomington: Indiana University Press; 2004. p. 215-33.

Weishampel DB, Dodson P, Osmólska H, editors. The Dinosauria. 2nd ed. Berkeley: University of California Press; 2004. p. 861.

Witmer LM. Perspectives on avian origins. In: Schultze H-P, Trueb L, editors. Origins of the higher groups of tetrapods: controversy and consensus. Cornell University Press: Ithaca; 1991. p. 427-66.
$\mathrm{Xu} \mathrm{X}$, Norell MA. A new troodontid dinosaur from China with avianlike sleeping posture. Nature 2004;431:838-41. doi:10.1038/ nature 02898.

Zelenitsky D. Reproductive traits of non-avian theropods. Journal of the Paleontological Society of Korea. 2006;22:209-16.

Zhou Z. The origin and early evolution of birds: discoveries, disputes and perspectives from the fossil record. Naturwissenschaften 2004;91:455-71. doi:10.1007/s00114-004-0570-4.

Zhou Z, Zhang F. Largest bird from the Early Cretaceous and its implications for the earliest avian ecological diversification. Naturwissenshaften 2002;89:34-8. doi:10.1007/s00114-0010276-9.

Zhou Z, Zhang F. Jeholornis compared to Archaeopteryx, with a new understanding of the earliest avian evolution. Naturwissenshaften 2003;90:220-5.

Zhou Z, Zhang F. Discovery of an ornithurine bird and its implication for Early Cretaceous avian radiation. Proc Natl Acad Sci USA. 2005;102(52):18998-9002. doi:10.1073/pnas.0507106102. 